\title{
A Descriptive Study on Reading Comprehension on Descriptive Text of The Seventh Grade Students at SMP Negeri 2 Rogojampi in The Academic Year 2013/2014
}

\author{
Irawati \\ English Educational Departement, Universitas PGRI Banyuwangi
}

Received : :Tuesday, October 10, 2017

Revised : Thursday, October 12, 2017

Accepted : :Monday, October 30, 2017

\section{Abstract}

The main purpose of conducting this research was to measure how far the reading comprehension in descriptive text of the seventh grade students of SMP Negeri 2 Rogojampi in academic year 2013/2014. There are three indicators in this research. Those are comprehending words, comprehending sentences, and comprehending paragraphs.

In this research, the researcher used descriptive quantitative research. The data was in the form of student's reading comprehension score. The instrument that is used in this research is a test. The kind of the test that used is multiple choice test. There are 20 items in the test covering identifying synonym, identifying reference, comprehending sentences, identifying main idea, and identifying the topic. The score for each item is 5 and the maximal score is 100.

From the data analysis of the research findings and discussions, the researcher found the minimum score is 50 and the maximum score is 95 . The average or mean of student's reading comprehension score is $75.98 \%$. It was in the range between71-80. It means that in general, the student's reading comprehension on descriptive text was good. The students' reading comprehension on descriptive text in comprehending words was $81.2 \%$. It was in the range between $81-90$. It can be said that the students reading comprehension in comprehending words was very good. The students' reading comprehension on descriptive text in comprehending sentences was $81.5 \%$. It was in the range between81-90. It can be said that the students reading comprehension in comprehending sentences was very good. The students' reading comprehension on descriptive text in comprehending paragraphs was $63.9 \%$. It was in the range between61-70. It can be said that the students reading comprehension in comprehending paragraphs was more than enough.

There are some suggestion given to the English teacher, the students and the other researcher. (1) The teacher should use the information about their student's reading comprehension on descriptive text as reflection to overcome their student's problems. The English teacher should find an effective way on their teaching learning process to increase the student's reading achievement. (2) The students should learn more about reading comprehension, especially in comprehending words, comprehending sentences, and comprehending paragraphs. (3) For the other researcher, it can be used as the basic for conducting experimental research or classroom action research to solve the 
student's reading comprehension problems, especially for comprehending paragraphs.

\section{Keywords:Descriptive Study; Reading Comprehension; Descriptive Text}

\section{A. Introduction}

Based on English curriculum 2013 for junior high school, the English subject given has an aim to improve the capability of communication. The based competence in new curriculum, include functional discourse which is focused on

listening, reading a description (people, thing and animal). The recent curriculumin Indonesia is curriculum 2013. It stated that the changing of teaching-learning methodology towards teaching-learning process is to enhance the values of competitiveness (Kemendikbud, 2012: 10). The (English) teaching-learning materials of the "2013 curriculum" should be relevant to competencies needed by the learners and job markets (Kemendikbud, 2012: 25).

In every subject, students activities involve reading. It also important for everybody in order to cope with new knowledge in the changing world of technological age. Reading has an important role in every aspect of our life. Reading skill also becomes very important in education field, students need to be exercised and trained in order to have a good reading skill. Reading is also something crucial and indispensable for the students, because the success of their study depends on the greater of their ability to read. If their reading is poor, they are very likely to fail in their study or at least they will have difficulty in making progress. On the other hand, if they have good ability in reading, they will have a better chance to success in their study.

One of the best ways to help students increase their language proficiency is to encourage them to read extensively. Based on informal interview conducted with the English teacher of the English program of the seventh grade students at SMP Negeri 2 Rogojampi, most of their students less interest in reading because of vocabulary. The lack of vocabulary has become one of the reason students cannot comprehend the text well. Beside it, the English grammatical structure is different from their first language. So, the students often confuse in learning English mainly to comprehend a text. Actually it is very difficult to telleverything about reading comprehension. The respondents are not interested in increasing about their reading comprehension. Therefore, the students usually get difficulties to catch the achievement.

To measure how far the student's reading comprehension on a text, the researcher was interested to conduct a simple research entitled "A Descriptive Study on Reading Comprehension on Descriptive Text of the Seventh Grade Students at SMP Negeri 2 Rogojampi in the Academic Year 2013/2014".

\section{Problem of the Research}

Based on the background of the research above, problem of the research can be stated as follows: 
a. The General Problem

How is the reading comprehension on descriptive text of the seventh grade students of SMP Negeri 2 Rogojampi in the academic year 2013/2014?

b. The Specific Problem

The specific Problems of this research are as follows:

1) How is the comprehension of words on descriptive text of the seventh grade students of SMP Negeri 2 Rogojampi in the academic year

2) $2013 / 2014$ ? How is the comprehension of sentences on descriptive text of the seventh grade students of SMP Negeri 2 Rogojampi in the academic year 2013/2014?

3) How is the comprehension of paragraphs on descriptive text of the seventh grade students of SMP Negeri 2 Rogojampi in the academic year 2013/2014?

\section{Objective of The Research}

There are two kinds of objectives of this research, the general objective and the specific objectives:

a. The General Objective

To measure how far reading comprehension on descriptive text of the seventh grade students of SMP Negeri 2 Rogojampi in the academic year 2013/2014.

b. The Specific Objective

1) To measure how far the comprehension of words on descriptive text of the seventh grade students of SMP Negeri 2 Rogojampi in the academic year 2013/2014

2) To measure how far the comprehension of sentences on descriptive text of the seventh grade students of SMP Negeri 2 Rogojampi in the academic year 2013/2014.

3) To measure how far the comprehension of paragraphs on descriptive text of the seventh grade students of SMP Negeri 2 Rogojampi in the academic year 2013/2014

\section{Significance of The Research}

The results of this research are expected to give good contribution to the following people:

a. The English Teacher

The result of this research are hopefully useful for English teacher as the information to know the student's reading comprehension skill on descriptive text and identifying the students vocabulary mastery, so that they can find the effective learning media, the appropriate techniques and teaching material which is related with the topic being discussed as well as choose the best way to overcome the students problems.

b. The Students

It is hoped that the students can take some information to identify their problems especially in reading. Furthermore, the results of the test given are hopefully useful for the students as the information to measure their reading comprehension skill in 
descriptive text. It is hoped, they will increase their ability in reading in order they will be motivated to improve their ability in reading and understanding about descriptive text

c. The other Researcher

The result of this research can be used by other researcher as a reference for further research dealing with the similar topic or to overcome the students problem in reading comprehension for instance as the basic for conducting classroom action research.

\section{Limitation of The Research}

The research focus on the students reading comprehension on descriptive text. The reading comprehension involves some aspects those are: comprehending words which discussed about identifying synonym and identifying reference. Comprehending sentences, includes identifying general and specific information based on the text that has been provided. The last is, comprehending paragraph which is covering identifying main idea and identifying topic. The descriptive text used is about describing people, things and tourism object.

\section{Operational Definition of Key Terms}

In order to avoid misunderstanding between the writer and the readers about the meanings of the terms used, the following are the definition of the terms used in this research. Those are reading comprehension and descriptive text.

a. Reading Comprehension

The researcher focuses on reading comprehension. Reading comprehension defined as the level understanding of a text or message. This understanding comes from the interaction between the words that are written and how they trigger knowledge outside the text or the massage. In this research, reading comprehension means the seventh grade student's ability in comprehending descriptive text, covering comprehending words, comprehending sentences and comprehending paragraphs

b. Descriptive Text

According to Djauhari (2007:24) descriptive text is a text which described and gives more detail information about particular people, thing, place, and animal. The general structure of descriptive text consist of : Identification (to identify the phenomenon to be described/mention the special participant), Description (mention the part, quality and characteristics of the subject being described). In this research, the descriptive text is a text that describes about people, things and tourism object.

\section{B. Reading and Descriptive Text}

\section{Reading}

The essential purpose of reading generally is to get new information or pleasure. Reading for information is reading that the 
reader has not stop to analyze the grammatical structures, the reader understand the structure without thinking about it. Reading for information requires that the reader understand the meaning of the passage. In addition, Nuttal (2005:3) state that whatever your reason for reading (excluding any reading for language learning), it is not very likely that you were interested in the pronunciation of what you read, and even less likely that you more interested in the grammatical structured used. You read because you wanted to get something from the writing.

Nowadays reading becomes more and more important. In the development of science and technology, being able to read well is very beneficial. Moreover, to some extent reading is required such as at work and at school. Indriati (2011:63) state that reading is a basic skill that should be mastered by students. Because reading cannot be separated from learning activity, it becomes an activity which is always done in the classroom.

Reading is very important in mastering English. In the school, students should comprehend the text they have read in order to gain meaning from the text. But, the fact is most of students less in reading. Therefore, many teachers use many ways to improve their students' interest in reading. Indriati (2011:63) says interesting reading materials will attract students to read it. Indriati (2011:64) ads that the first thing that students should in reading is having interest in what they will read. If they are interested in what they are going to read, it will help them so much in understanding the materials they read. The important thing to improve student's interest in reading is give them understanding about the importance of reading activity for themselves to improve their knowledge development.

\section{Descriptive Text}

One of genres that Junior High School students learnt is descriptive text. Based on Competency Standard (Standar Kompetensi) and Basic Competency (Kompetensi Dasar), the second year students are expected to be able to understand and respond meaningful written text in term of functional written text and simple short essay in the form of descriptive and recount text interact with people in the nearest environment (Depdikbud 2006). According to Djauharie (2007:24) descriptive text is a text which describes and gives more detail information about particular people, thing, place and animal. It means that descriptive text tells the reader to know about something specifically by giving characteristic of something which described.

The researcher concludes that descriptive text is a text which describes something and includes of the characteristic and qualification of something, someone or somewhere.

c. The Generic Structure of Descriptive Text

An effective descriptive text has several significant characteristics which the reader may use as standard to guide his or her reading. According to Hartono (2005:7) the general 
structure of descriptive text consists of identification and description. The explanations of each part are follows:

The first part of generic structure in descriptive text is identification. Identification introduces and identifies anything or phenomenon which is described. It has function to bring reader to introduce what will be discussed. Like orientation of other genres, identification is usually put in first paragraph. It is as introduction to reader to read next paragraph. Identification usually answers the questions; what is the topic of the text, and what is the text above.

The second part of generic structure in descriptive text is description. Description is part of generic structure that consist of particular phenomenon or thing. It is the main of issue that has a characteristic which distinguish with other genres. The description has function to describe parts, qualities, and characteristic of the parts of the object. It is put after identification or next paragraph of identification until final paragraph. In example, if we describe the class room, wemention parts of classroom as its doors, chairs, table, and walls. We mention characteristic of the classroom as big (size),

\section{Research Method} green (color), or clean (quality)

\section{Research Design}

Latief Adnan (2010:67) state that in quantitative research, the forms and the types of data to be collected are already designed certainly before the collection data begins. Another statement from Latief Adnan (2010:68) the research data in quantitative method always be in number or numerical (or symbol such as A, B, C, D). In This research, the data is in the form of student's reading comprehension score. Hence, the research design is categorized as "descriptive quantitative research". The researcher used descriptive quantitative research. Because the objectives of this research is to know and measure the capability on understanding the reading comprehension on descriptive text of the seventh grade students at SMP Negeri 2 Rogojampi in the Academic Year 2013/2014.

\section{Research Area}

In conducting a research, it is essential for the researcher to determine the research area. In this research, purposive area method is used. The area chosen is

SMP Negeri 2 Rogojampi which has become one of National Standard School in Banyuwangi. It located in Jalan Pangeran Diponegoro no.77. There are 38 teachers in this school and 4 of them are English teacher. Teaching hour for every subject is $2 \times 40$ Minutes. This school also has a language laboratory which is supported by complete facilities such as computers, student's headset, air conditioner (AC), TV, etc. 


\section{Research Subject}

A research usually takes some parts of reached population which is called sample (Latief Adnan, 2010:138). There are eight classes in seventh grade student at SMP Negeri 2 Rogojampi. In this case, researcher applied cluster random sampling because the population is in the cluster or group form. Arikunto (1998:127) also said that "Cluster sampling" is used in the research if in population there are some groups that have different characteristic. Ali (1984:67) defines "cluster sampling" as a sampling based cluster not individually. The population is divided into group or unit based on area or cluster. The subject chosen is the class VII A. There are 36 students in this class which are divided into 16 for male students and 20 for female students.

\section{Data Collecting Method}

Research instrument plays an important role in research project. The data was students reading comprehension score. In this research, the researcher uses one instrument to collect the data. The instrument that is used in this research is a

test. Arikunto (2006:150) state that a test is series of question or exercise to measure skill, knowledge, intelligence, ability or talent that is processed by individual or groups. The kind of the test that used in this research is multiple choice test. It is chosen because it make easier for teacher to score. There are 20 items in this test covering identifying synonym, identifying reference, comprehending sentences, identifying main idea, and identifying the topic.

\begin{tabular}{lllc}
\hline No & Indicators & Number & Total Items \\
\hline $\mathbf{1}$ & Comprehending Words & & \\
& Identifying synonym & $1,7,15,16$ & 4 \\
& Identifying reference & $2,3,12,17$ & 4 \\
\hline $\mathbf{2}$ & Comprehending sentences & $\begin{array}{l}4,8,9,11, \\
18,19\end{array}$ & 6 \\
\hline \multirow{2}{*}{$\begin{array}{l}\text { Comprehending } \\
\text { Paragraphs }\end{array}$} & & \\
$\mathbf{3}$ & Identifying Main Idea & $5,6,13,14$ & 4 \\
& Identifying The Topic & 10,20 & 2 \\
\hline & Total & & 20 Items \\
\hline
\end{tabular}

Table 01. Distribution of the test items

\section{Data Analysis Method}

The collected data has analyzed by using percentage. The students' reading comprehension scores obtained from the test were computed quantitatively. Then, the result of this data will be used to answer the research problems. The percentage formula is as follows:

$$
\sum \frac{n}{N} \times 100 \%
$$


E : The percentage of total score

$\mathrm{n}$ : The score obtained by the students

$\mathrm{N}$ : The total score of the item

(Adopted from Ali, 1993:186)

\begin{tabular}{ll}
\hline Criteria of Mastery & Grade \\
\hline $\mathbf{9 1 - 1 0 0}$ & Exellent \\
\hline $\mathbf{8 1 - 9 0}$ & Very Good \\
\hline $\mathbf{7 1 - 8 0}$ & Good \\
\hline $\mathbf{6 1 - 7 0}$ & More than enough \\
\hline $\mathbf{5 1 - 6 0}$ & Poor \\
\hline Less than $\mathbf{5 0}$ & Very poor
\end{tabular}

\section{Result and Discussion}

The test was used to get primary data about the student's reading comprehension on descriptive text. The test was conducted on May 24, 2014. The number of reading comprehension test was 20 items in the form of multiple choice and covered identifying synonym (4 items), identifying reference ( 4 items), comprehending sentences ( 6 items), identifying main idea (4 items), and identifying topic ( 2 items) dealing with the scoring each correct answer was scored 5. Thus, the total score of the correct answer was 100.

\section{The test result of Reading Comprehension and Descriptive Text}

Based on the classification of students' reading comprehension on descriptive text, the researcher has known that their ability in English reading comprehension was $76 \%$ (see appendix 5). It was in the range between 71-80. It means that on the average the classification of the student's reading comprehension on descriptive text score was "Good". The higher percentage was in comprehending sentences while for comprehending words was more than enough and the lowest percentage was in comprehending paragraph.

a. Comprehending words

The result of the student's reading comprehension in comprehending words was $81 \%$. It was in the range of 81-90. It means that on the average, the classification of the students reading comprehension in comprehending words was very good. (see appendix 6)

There were 11 students had scores between $91-100$. The students' reading comprehension on descriptive text mean scores was $31 \%$. It can be said that the student's score was excellent. Then, 5 students who had scores between 81-90, it can be said that $13 \%$ of the students' score was very good. There were 11 students who had scores between71 - 80. It can be said that $31 \%$ of the students' score was good and there were 9 students who had scores between 61-70, it can be said that

$25 \%$ of the students' score was more than enough (see appendix 6). In comprehending words, the lowest student's 
score was in reference. The mean score of reference was $75 \%$ while the mean score of synonym was $88 \%$.

b. Comprehending sentences

The result of the student's reading comprehension in comprehending sentences was $80 \%$. It was in the range of 71 80. It means that on the average, the classification of the students reading comprehension in comprehending sentences was good.

There were 9 students who had scores between 91 - 100. The students' reading comprehension on descriptive text mean scores was $25 \%$. It can be said that the student's score was excellent. Then, 14 students who had scores between

$81-90$, it can be said $39 \%$ of the students' score was very good. There were 11 students who had scores between 61-70, it can be said that $31 \%$ of the students' score was more than enough and there were 2 students had scores less than 50 , it can be said that $5 \%$ of the students' score was poor.

c. Comprehending paragraph

The result of the student's reading comprehension in comprehending paragraphs was $64 \%$. It was in the range of 61 70. It means that on the average, the classification of the students reading comprehension in comprehending paragraph was more than enough.

There were 13 students who had scores between $81-90$. The students' reading comprehension on descriptive text mean scores was $36 \%$. It can be said that the student's score was very good. Then, 12 students who had scores between

61-70, it can be said 33\% of the students' score was more than enough and there were 11 students who had scores less than 50 , it can be said that $31 \%$ of the students' score was poor (see appendix 6). In comprehending paragraphs, the

lowest student's score was in topic. The mean score of

\section{E. Discussion} topic was $56 \%$ while the mean score of main idea was $68 \%$.

After conducting reading comprehension test, the researcher found the minimum score for reading comprehension on descriptive text is 50 and the maximum score is 95 . The average or mean of student's reading comprehension score is $76 \%$ (see appendix 5 ). It was in the range between 71 - 80. It means that in general, the students reading comprehension on descriptive text of the seventh grade students at SMP Negeri 2 Rogojampi in academic year 2013/2014 was good. It was supported by the students' achievement and activity in learning English in the class.

The students' reading comprehension on descriptive text in comprehending words of the seventh grade students at SMP Negeri 2 Rogojampi in academic year $2013 / 2014$ was $81 \%$. It was in the range between 81 - 90. It can be said that the students reading comprehension on descriptive text in comprehending words was very good. It means 
that the students are able to comprehend word meaning from the text which is given by their English teacher. The highest score of comprehending words was 100 and the lowest score was 62.5.

In comprehending words, there are two sub indicators. Those are synonym and reference. The mean score of synonym was 87.5 while the mean score of reference was 75 . For the synonym, students got difficulties in number 16. There are only 25 students who answer the test correctly and the percentage of correct answer was $69.4 \%$. For reference, students got difficulties in number 12. There are only 21 students who answer the test correctly and the percentage of correct answer was $58.3 \%$

The students' reading comprehension on descriptive text in comprehending sentences of the seventh grade students at SMP Negeri 2 Rogojampi in academic year $2013 / 2014$ was $80 \%$. It was in the range between 71 - 80 . It can be said that the students reading comprehension on descriptive text in comprehending sentences was good. It means that the students are able to comprehend sentences, include identifying general and specific information based on the text that has been provided. The highest score of comprehending sentences was 100 and the lowest score was 50. In comprehending sentences, students got difficulties in number 18. There are only 9 students who answer the test correctly and the percentage of correct answer was $25 \%$.

The students' reading comprehension on descriptive text in comprehending paragraphs of the seventh grade students at SMP Negeri 2 Rogojampi in academic year $2013 / 2014$ was $64 \%$. It was in the range between 61 - 70. It can be said that the students reading comprehension on descriptive text in comprehending paragraphs was more than enough. It means that the students are able to comprehend paragraph from the text. The highest score of comprehending paragraphs was 100 and the lowest score was 33.3.

In comprehending paragraphs, there are two sub indicators. Those are main idea and topic. The mean score of main idea was 68 while the mean score of topic was 56 . For the main idea, students got difficulties in number 6 . There are only 3 students who answer the test correctly and the percentage of correct answer was $8 \%$. For topic, students got difficulties in number 20 . There are only 13 students who answer the test correctly and the percentage of correct answer was $36 \%$.

The result showed that in general, reading and comprehension are two terms which are always interrelated. In reading, there will be a process to understand and comprehend a text. A text consists of words, sentences and paragraph. It means that to understand the content of the text includes the general and specific information, students should comprehend words, sentences and paragraph in that text. In this research, we know that comprehending words, comprehending sentences and comprehending paragraphs is a unity that is interrelated each other. We cannot comprehend a sentence without knowing the meaning of the words first. We also cannot comprehend a paragraph without knowing the meaning of each sentence include in it. So, it 
is clearly that vocabulary mastery has an important role in reading comprehension

\section{F. Conclusions}

In general, the student's reading comprehension on descriptive text was categorized as good (76\%). The research result could be concluded as follows:

1) On the average, the student's reading comprehension on descriptive text in comprehending words was in category of very good (81\%)

2) On the average, the student's reading comprehension on descriptive text in comprehending sentences was in category of very good (80\%)

3) On the average, the student's reading comprehension on descriptive text in comprehending paragraph was in category of more than enough (64\%)

\section{G. Acknowledgement}

First of all, I would like to express my thanks to ALLAH SWT, that always leads and gives are bright think and health so that I can finish this thesis.

My gratitude addressed to the following people:

1. The Rector of PGRI Banyuwangi University (UNIBA)

2. The Dean of Faculty of Language and Art of PGRI

3. The Chief of Research Center PGRI Banyuwangi University

4. The Chairman of English Educational Department of Faculty of Language and Art of PGRI Banyuwangi University

5. The First and Second Consultant

6. All the lectures at the English Educational Department of UNIBA

7. The headmaster, the teachers the administration staffs and all students of SMP Negeri 2 Rogojampi

8. All my friends who supported me to finish this thesis

Finally, the researcher realized that this thesis is far from being perfect. That is why I do hope suggestion, construction, criticism and thoughtful from all the readers to make this thesis better.

\section{H. Reference}

Alyousef, H.S. (2005). Teaching Reading Comprehension to ESL/EFL Learners. Vol 5 No 2, September 2005. Http://www.Readingmatrix.com/articles/alyousef/article.pdf [accessed on 2 nd of May 2014]

Arikunto, S. (2010). Prosedur Penelitian. Jakarta: Rineka Cipta

Brenda, D. Smith. (2010). Breaking Through: College Reading.Http://www.pearsonhighered.com/samplechapter/02 05734367_ch04.pdf [accessed on 7 th of May 2014]

Brown, H.D. and Abeywickrama, P. (2010). Laanguage Assesment. New York: Pearson Education

Cahyono, B.Y and Kusumaningrum, S.R. (2011). Practical Techniques for English Language Teaching. Malang: State University of Malang Press 
Christine Nuttal. (2005). Teaching Reading Skill in a Foreign Language. London: Mc Millan.

Depdikbud, Kurikulum Tingkat Satuan Pendidikan. (2006). Standar Isi SD, SMP dan SMA. Jakarta: Depdikbud 2006

Grabe, W. (2009) Reading in a Second Language: Moving From Theory to Practice. New York: Cambridge University

Hudson, T. (2007). Teaching Second Language Reading. New York: Oxford University Press

Huford, J.R. (2007). Semantics. New York: Cambridge University Press. Latief, M.A. (2010). Tanya Jawab Metode Penelitian Pembelajaran Bahasa. Malang: Unersitas Negeri Malang (UM Press)

Mikulecky, B.S. and Jeffries, L. (2007). Advanced Reading Power. New York: Pearson Education.

Mikulecky, B.S. (2011). A Short Course in Teaching Reading. Ney York: Pearson Education

Otong Setiawan Djauharie. (2007). Genre Dilengkapi 700 Soal Uji Pemahaman.Bandung: Yrama Widya

Rudi Hartono. (2005). Genres of Text (Unpublished Paper). Semarang: Semarang State University English Department Faculty of Language and Art

Sugiyono. (2011). Metode Penelitian Kuantitatif dan Kualitatif, dan R \& D. Bandung: Alfabeta

Timothy Bell. (2001). Extensive Reading: Speed and Comprehension. Vol 1 No 1, April 2001. Http://www.Readingmatrix.com/articles/bell/index.html [accessed on 7 th of May 2014].

Woolley, G. (2011). Reading Comprehension: Assisting Children with LearningDifficulties.Http://www.springer.com/cda/content/do cument/cda_download document/9789400711730c1.pdf?SGWID=0-0-45-1 158048- P174102871 [accessed on 7 th of May 2014]. 